\title{
Disciplinary Anxieties in the Study of Religion
}

\author{
WILLI BRAUN \\ University of Alberta
}

\begin{abstract}
After remarking on some common worries that trouble the academic study of religion, the article presents an argument for an anthropocentric stance and analytic preference as the directional compass, or an intellectual alignment, in the disciplinary practices of Religious Studies. At the core of this stance is a 'reductionist' commitment to a corrigible theoretical monism, which is, however, compatible with plural analytics or methodologies.
\end{abstract}

Keywords: Study of religion, theories of religion, disciplinarity

Research is formalized curiosity [...] is poking and prying with a purpose (Hurston 1942, 74).

Many disciplines, including Religious Studies, are undergoing a period of lamentation over a perceived slippage in, or fragmentation of, disciplinary identities. The reasons are multiple: older notions of disciplinary knowledge systems have been destabilized by forces that are familiar to us all. Indeed, the notion of disciplinarity itself is under question. ${ }^{1}$ In Canada at least, economically imposed anorexic regimens in the universities during the last two decades have left the human sciences, Religious Studies among them, scrambling for institutional space, resources and, therefore, license (see Gardaz 2006). And, this scramble entails in part disciplinary self-scrutiny as a matter of (often self-defensive) rationalizing of Religious Studies' intellectual contributions to the academy's study of humankind across time and space. As is often the case, situational changes do present opportunities for reviewing disciplinary practices, even for inventing new

\footnotetext{
${ }^{1}$ See Messer-Davidow et al. 1993; Hertz 1994; Thompson Klein 1996. To this selective list could be added meditations on disciplinary identities and practices within specific fields of study, notably anthropology and history.
} 
ones. So, this occasion does represent an opening for wading into what I take to be a combination of cliché-ridden ennui and ideational unrest, if not anxiety, concerning questions on what distinguishes the study of religion as an academic field. That is, on what account is the study of religion to live another day in the academy of learning? How does the scholar of religion define the raison d'être of her or his labours? My meditation to follow does not lay out a full answer, not even the elemental forms of an answer, but addresses the question of stance, or intellectual disposition, that might direct the disciplinary practices of Religious Studies.

A common frustration for scholars of religion concerns the restrictions, often self-restrictions explicitly invoked or tacitly obeyed by students at all career stages, that are placed on curiosity: the 'better not ask' or 'better not go there' affective stances that are laid down as obstacles to the pursuit of a disciplined drive toward a cogent intelligibility of the human practices we have come to call, in virtue of some stipulated markers, 'religion' or 'religious'. The Pandora of myth is still censured in the academy, it seems, as the arch- or original sinner, the anti-model of intellection, that evil woman (it would be a woman, of course) whose curiosity released a can of toxic worms that kills cats, rather than as the mythic hero of curiosity as the giver of everything - which is what Pandora means. This restriction of curiosity, especially prevalent in the study of religion, poses an important threat to academic freedom (at least in North America); perhaps the greatest threat, since it does not come from institutional strictures but from a cultural censure of unbounded curiosity, that might in fact be diagnosed as a gendered anxiety about the corrosive effect of the Pandora complex. Within the study of religion the Pandora complex is seen as a veritable toxin that might kill the power of the gods. Hence Pandora is a metaphor that chidingly stands as a warning against an anthropocentric scholarly stance and analytic preference in the study of religion. It is this stance, anxieties over it, and resistance to it, that I want to worry about briefly, for it is crucial in the introduction of religion in the collegiate domain.

\section{‘Religion' as Untouchable?}

By 'anthropocentric stance and analytic preference' I mean something like the following: There is no religion in-it-self apart from people who do things that either those who do them or scholars of religion (or both) call 'religious', though with different meanings of the term 'religious'. In that 
sense, religion does not exist (let's not conflate nomenclature and ontology); ${ }^{2}$ all that exists for our study are people who do things that we classify as 'religious' by means of various definitional criteria (see Arnal 2000). For the scholar of religion this entails, first, that the gods are not given a say in our sense-making of religious affairs; it entails that the gods are truly regarded by religion scholars as among the deaf and mute, among $\tau \dot{\alpha} \alpha \not \alpha \omega v \alpha$ (the speechless), to speak biblically (1 Cor. 12:2). I am alluding here to what Hans Penner articulates with reference to the study of myths:

After many years of false starts we should do our best to put aside the long tradition that translates myth as a revelation of a mystery, a code that must be decoded, or a complex multivalent symbolic system of some deep psychological or metaphysical domain. In brief it is best to put aside all the intellectual effort, which at times has been brilliant, that tried to demonstrate that the basis, the foundation, of the meaning of myth is referential, or, representational. (Penner [forthcoming], 1-2; cited from typescript.)

Second, it entails that the proper object of the scholar's study consists of the 'religious' behaviours of people, a study that consists of description and explanation in general anthropocentric terms. In the words of Alexander Pope (1733): 'Presume not God to scan / The proper study of mankind is Man.' Thus, even when we study objects that in the religious doings of religious people represent themselves as the 'presence' of the gods, it is people who make this representation of 'presence'. For example, as I tell my students who come into my course on the New Testament and other early Christian writings, even when we study the Bible - the 'word of god' - we shall be studying the human interests in representing texts (or anything else) as divine rather than human and the historical, social, and political effects of these representations.

As a scholar of religion I find that this is a crucial conceptual threshold that many students find difficult to cross; one, therefore, that has to take

\footnotetext{
${ }^{2}$ This conflation has long been noticed by historians of the popular use of language and students of so-called 'magic'. For example: 'So lässt nun auch das Volk, im lebendigen Gefühle, den namen eines Dinges nicht gern als todtes Zeichen: weil ihm nämlich "heissen" und "sein" zusammenfällt. Es denkt im Worte die Sache; es sagt z. B. das is Brod. Hier wird nicht, abgesehen vom Wort, ein Ding gedacht, welches den Namen Brod trägt; sondern im Namen wird das Ding Brod gedacht.' - 'The Volk is not sentimentally inclined to permit the name of a thing to be a dead sign, because for it "being named" and "being" belong together. It thinks the thing in the word; it says, for example, this is bread. Here a thing, which carries the name bread, is not thought apart from the word; rather, in the name the thing bread is thought.' (Steinthal 1863, 5 , my translation.) Note the observations by Tim Murphy $(2006,204-306)$ on the attribution of concreteness to the word 'religion' in the popular discourses of North Americans.
} 
up a significant amount of time in the religion scholar's work, whether in the study or in the classroom. This is not the place to worry at length over the reasons for this difficulty, but only to surmise that they are rooted in at least three complementary default affects:

(1) A general inclination toward an idealism which regards ideas - and the beliefs, experiences, sentiments associated with these ideas - as an autonomous realm of things apart from social contexts, and concludes therefore that ideas ought to be examined on their own terms. Or, in converse terms, there is a diminution of materiality, insomuch as the tangible world of human doings is seen merely as a transitory site where the otherwise autonomous ideational entity is housed, expressed, symbolized, and practiced;

(2) A general inclination, induced by the forces of our culture, to regard religious ideas in hyper-idealist terms, such that we are seduced into a desire for an analytic that is commensurate with the topical orientation of religious ideas toward gods and ghosts and inscrutable human hearts - that is, with the topical 'it' of religious discourses rather than with the people and societies that constitute, rationalize, defend, contest, and identify themselves in complex ways by means of these discourses in socially, materially, and historically, located contexts;

(3) a general inclination to set off these hyper-idealist religious ideas as the privileged articulation of a timeless, self-validating truth, rather than thinking of ideas too as practices, that is, ideas as effects of and subject to or complexly in the service of human practices (see Stowers 2007; forthcoming).

Despite the prevalence of these default assumptions, it ought to be said that ideas are not autogenetic; they do not think themselves; they do not selfevidently communicate their own meaning. And, even once they are thought and articulated by thinkers, they do not have practical force unless they are given force by people (see further Arnal \& Braun 2004). History is, after all, littered with graveyards of rusty and never-mobilized ideas, much as many rural Alberta highways are decorated with rusted, dead automobiles.

Taking seriously that it is people who think and do things and that ideas do not think themselves means that we should adopt a thoroughgoing 'anthropocentrism', in which our object of study are the people (which includes their behaviours and their institutions) who discursively think the gods into existence. In turn, this means that one's dealing with religious phenomena at the very least begs for an examination of these idealist affective stances - not to speak of offering some of the conceptual tools for proceeding with such an examination, and, at its strongest, resisting the inclination to sever ideas, even right godly ones, from social provenances and processes. 


\section{The Need for Ethnography - In What Sense?}

With reference to introducing religion in an anthropocentric key - indeed, as an anthropological category - this means that we paraphrase a point made by the anthropologist John Comaroff on the relationship between 'history' and 'anthropology': A theory of religion which is not at the same time a theory of society is hardly a theory of religion at all (Comaroff 1982; see also Comaroff \& Comaroff 1992, 13-18). The reverse also holds true, I suggest: a theory of society that is not at the same time a theory of religion is hardly a theory of society at all, given that all so-called 'religious' practices are an integral part of the societies in which they are found. ${ }^{3}$

That this must entail that the scholar of religion becomes a certified social scientist, an ethnographer or anthropologist, as I am sometimes told - most recently by an anthropologist, who, equating anthropology with ethnography, suggested to me that I should not use the word 'anthropological' unless that means doing ethnography in the field - is not evident to me. ${ }^{4}$ In any case, which ethnography? Riding which theory of ethnography? As if ethnography is a self-evident stand-in for theorizing religion, or as if ethnography is itself not something that is riding on or in service of a theory. I would most certainly demur against a concomitancy between an anthropocentric-social study of religion and a certain kind of ethnography, the symbolist-hermeneutic-ethnographic anthropology that Marvin Harris labelled 'emic' (1980, 32-41). I get very nervous when the term 'ethnography' is shorthand for the view that the scholar must go 'native', in a quest for empathetic replication of the epistemologies of adherents to whatever religion the scholar is studying, such that the scholar is then in a position to speak for, perhaps speak the (no preposition needed) adherent. This kind of ethnographic motive is the reappearance or afterlife of the legacy of the so-called phenomenological approach that continues to dominate much of the academic study of religion in North America, currently often under transmuted terms in which the phenomenologist's desire to protect an ontological Religion lives on. I am thinking of terms such as 'post-colonialism', 'indigeneity', 'alterity' and/or 'authenticity' ${ }^{5}$ - recognizing, of course,

\footnotetext{
${ }^{3}$ For implications, which cannot be fully worked out here, for re-conceptualizing the relationship between the scholarly practice of theology and the study of religion, see Arnal \& Braun (forthcoming).

${ }^{4}$ This is not to say that the study of religion is not more closely aligned with anthropology and history than with some other disciplines. See Smith 1978, 290-291.

${ }^{5}$ On the rhetoric of authenticity: It should be noted that in the current affective conditions of the academy (but hardly only or especially in the academy), often imprecisely intoned in terms of 'postmodernism' or 'postcolonialism' and associated with 'experience' or 'indigeneity' or putatively nativistic politics as a privileged epistemological stance, the myth of authenticity continues to be seductive, especially, perhaps, in the study of religion (see McCutcheon 2003; Sayeed 1995). On the myth of authenticity in late modern discourse, in circles greatly influenced by M. Heidegger, see Adorno 1964; and, generally, Griffiths 1989.
} 
that these terms are themselves divergently thought and contested. This kind of ethnographic motive strikes me as suspect for two reasons. First, no amount of ethnography, however empathetic, will fulfil the desires which motivate it, that is, the desire of the ethnographer to know not only what but exactly how the informant knows what he or she knows. Second, to persist nonetheless in the quest for an intersubjective convergence between ethnographer-anthropologist and native-informant, such that the former might then be able to ventriloquate the subjectivity of the latter, strikes me as conceit bordering on hubris. I have decided that I cannot go there.

Rather, I use the term 'ethnography' as a general shorthand for gathering information or data, more specifically for gathering the kind of information that is not available to the scholar except by ethnographic techniques such as observation and interviewing. Ethnography is simply a means, a method, of gathering, describing, and classifying what people say and do; once I have that information, it is up me to subject it to explanation with respect to conceptual scheme or a theory-in-progress that is of my own devising. That is, I would like to make it clear that when we try to subject to our thought the information thus gathered, it is we who are trying to understand the data for our explanatory purposes. The 'natives' (people who practice religion) do not need me, and it is an act of academic hubris bordering on imperialism - or at the very least unflattering paternalism - to presume that they do. They already know what they do and why they do it; at least, whatever their knowledge about what they do and why they do it is sufficient and true for them. Even the late Clifford Geertz, who wanted to understand the Balinese cockfight from the 'native's point of view', recently said this in response to an interviewer's question as to whether the ethnographer should 'go back to the natives and show them one's results':

In general, no! [...] They are not interested in social science or alternative understandings $[\ldots]$ of what they are doing. They are not interested in the hermeneutics of cockfights. They already know what it [the cockfight] means to them. What I want to do is tell somebody, who does not already know what the cockfight means, what it means. (Micheelsen 2002, 10.)

Just so! Let this notion of an 'anthropocentric study of religion' stand for a kind of declaration, a thesis statement. Admittedly it is a statement with an attitude that generates either nervous or resisting responses from colleagues in the field and students in my classroom. Let me illustrate this nervousness with reference to two lengthy review articles on the Guide to the Study 
of Religion (Braun \& McCutcheon 2000), which tries, with 'attitude', ${ }^{6}$ to set forth the case for a thoroughly anthropocentric study of religion that owed much to Smith's conceptual instruction on what the religion scholar's work is about. One commentator characterizes this attitude by the term 'gnosticism', which I take to be in part a metaphor for immodesty regarding the certainty of knowledge presumed to be entailed in this attitude (see Desjardins 2001). Another commentator worried about the Guide's 'totalizing' desire that betrays an excess of confidence in the 'certainty of modernity', that is, a certainty that has not been sufficiently chastened by the postmodern critique of the bullet-proof epistemologies of post-Enlightenment or 'modern' scholarship (Whitcombe 2001). ${ }^{7}$ This same critic finds fault with what is perceived to be an imperious sense of 'superior wisdom' hidden in this 'attitude', a superiority marked by 'a striking disrespect' for and 'snub' of the knowledge of religious people about their own religiosity.

What I take to be the crucial issue here is a concern over scholarly 'attitude' as a desire for intellectual monarchy or theoretical imperialism. I accept the equivalence but do not share the concern, either in my scholarly work or as a teacher in the classroom. Concepts (that enable us to establish relations between apparently unlike things), theories (that enable us to account for the relations), and the methods of assembling and analyzing the objects of our scrutiny (which are none other than the disciplined acts by means of which theories are put into practice), once we commit ourselves to them, act like jealous lovers who insist that we permit them 'the kind of monomaniacal power or imperialism that a good method has when we are honest about it' (Smith 2007, 93). ${ }^{8}$ Theoretical mix-and-match, methodological profligacy, a come-one-come-all ecumenical generosity with respect to 'approaches' or elemental presuppositions are, in the final analysis, not in my lexicon of scholarly or pedagogical virtues. Why not? My answer begins once more with a quote from Jonathan Z. Smith:

Without the experience of riding hell-bent for leather on one's presuppositions, one is allowed to feel that methods have really no consequences and no

\footnotetext{
${ }^{6}$ This attitude is defended in Braun 2000, 3-18; it signals not an arrogant stance of being more deeply in the know, but an intellectual alignment, an 'angle of vision for the historian of religion', in J. Z. Smith's words (1982, xiii).

${ }^{7}$ Cf. my response to Desjardins and Whitcombe in Braun 2001, from which I have taken some material for this essay.

${ }^{8}$ The quote is from Jonathan Z. Smith's Afterword, 'The Necessary Lie: Duplicity in the Disciplines' (2007), in McCutcheon 2007 (cited from typescript with the permission of R. McCutcheon). I am here restating a point that is elaborated in Braun, 2000, 12: 'Concepts [...] are jealously discriminating romancers and lovers of explanatory stratagems that are commensurate with (faithful to) the core sensibilities of the concept.'
} 
entailments. Since none of them is ever allowed to have any power, none of them is ever subjected to any interesting cost accounting. (Smith 2007, 93.)

In other words, a theoretical and methodological 'fusion cuisine' (fashionably and ubiquitously called 'pluralism'), sometimes prescriptively adjured as a requirement of plain human decency or, perhaps more typically, thought to be mandated by a pseudo-postmodern abnegation of strong critical judgment, is corrosive of the very possibility of determined, disciplined, non-promiscuous explanatory intellection with respect to human, including religious, 'practices of everyday life' (arts de faire), as Michel de Certeau (1984) calls them.

In the realm of Religionswissenschaft (though also in other disciplines) this view takes the side of the methodological reductionists in their long (and mostly tedious) debate with the anti-reductionists. Why 'reductionism' is so often regarded as a 'dirty word' that is equated with a 'holier-than-thou self-righteousness' (Dawkins 1982, 113; cf. Sperber 1996, 5-6), and often associated with critiques arising from the work of interpretivists of what are considered the non-reducible, incommensurable religious whispers 'in' or 'behind' our data, is something that I find more amusing than puzzling, although in the classroom 'reductionism' is always a good entrée into the problematics of explaining human phenomena in translated terms, that is, in terms other than those in which the phenomena present themselves. Given that all scholarship involves disciplined acts of description, translation, and redescription, the terms 'reductionism' and 'anti-reductionism' should actually be retired without any loss for the academic study of religion.

\section{Fundamental Requirements for a Theory of Religion}

The binary, therefore, has devolved into something that is about as interesting as observing early Christians calling their marvels 'miracles' and other people's 'magic' - such terms are social devices that tell us nothing interesting about the object so named, but a great deal about the interests of the namer. Thus other terms are preferable, such as 'translation' of phenomena that seemingly and passively present and promulgate themselves in asocial, ahistorical, natural, idealist, non-anthropocentric terms, coming to understand them instead in terms of social, historical, material, anthropocentric categories. ${ }^{9}$

\footnotetext{
${ }_{9}^{9} \mathrm{~J}$. Z. Smith has persistently recommended 'translation' as a move in the effort to gain a cognitive hold on the unfamiliar. Among the most careful, precise statements on translation is his rectification of Durkheim's understanding of 'explanation' as the identification of a phenomenon's causes: 'A procedure where the unknown is reduced to the known by holding that a second-order conceptual language appropriate to one domain (the known, the familiar) may, with relative adequacy, translate the language appropriate to another domain (the unknown, the unfamiliar)' (Smith 2004, 106, 371-372; see also 2001b).
} 
So, 'attitude', which I equate with the 'monomaniacal' theorizing of religion (or for that matter anything else) is good; it is a requirement of intellection itself. But lest readers are not convinced - or, worse, lest they are tempted to take umbrage at this 'attitude' - allow me several amplifications and clarifications.

(1) Riding one's theory 'hell-bent for leather', whether in what one writes or in the classroom, is to be differentiated from social or political imperialism or even generalized intellectual imperialism. Riding like a bat out of hell, especially on the track (academy) to test the limits of machine (theory) and rider (scholar), is not an example of 'road rage' that aims at running other riders off the track. Although one should expect some abrasion - with Smith: 'You have to allow me some measure of monomania if I am to get anywhere. I can't do my work when I have to stop and entertain every other opinion under the sun. This is why such work must always be done in a corporate setting, so that the monomanias mutually abrade against, so that they relativize each other.' $(2007,98$.)

(2) Strong theorizing is not equivalent to presenting one's theory from behind a bullet-proof armour of dogmatism. Presuppositions, and the theories and methods that they generate, are corrigible generalizations, and should be held and presented as corrigible. ${ }^{10}$ Indeed, corrigibility and rectification are strong concomitants of monomaniacal theorizing, just as they are rather weak concomitants of all-inclusive, pluralist investigations of religious (or any other human) 'practices of everyday life'. Only what is truly tested can be corrected. How to put this aphorism into pedagogical practice is a challenge with implications for syllabus design, for student project design, and for managing the intellectual and affective mix of losses suffered and gains achieved.

(3) Monomaniacal theorizing is not the same as an analytical monism that can account for every jot and tittle of 'religious' social practice by means of a single analytical category, such as 'exchange theory' or 'rational choice

\footnotetext{
${ }^{10} \mathrm{~J}$. Z. Smith has long insisted on the 'general' against the 'universal', just as he repudiates the category 'unique', and rather prefers the term 'individual' because the latter 'permits the affirmation of difference [which "unique" does not] while insisting on the notion of belonging to a class' $(1990,37)$. Note the precision in Smith's formulation of the interdependence of generalization and corrigibility in the following: 'the "general" is placed in opposition to the "universal" by its admission to significant exceptions. Generalization is understood to be a mental, comparative, taxonomic activity that directs attention to co-occurrences of selected stipulated characteristics while ignoring others. Both of these qualifications, not universal and highly selective, are central to generalization. [...] Employed correctly, these same characteristics insure that generalities are always corrigible.' (2004, 369; see also 2001b, emphasis added.)
} 
theory' or 'ritual theory' or any other theory. For example, the social-historical processes by which some tales become authoritative myths while some authoritative myths devolve into mere tales may require a different explanatory scheme than why some people religiously justify going to war as a holy activity while other religious people think it is unholy. Nor does monomaniacal theorizing require that a general, all tidied-up theory of society and culture (if such is even possible) be in place prior to accounting for religion, religions, and religious doings in broadly social terms. Corrigible theoretical monism is compatible with plural analytics or methodologies, I propose. Think, thus, of the analytic categories and methods of the human and social sciences as a tool-shed for anthropocentric-social explanations of religious practices. The tools in the shed may need fixing, adapting, constant scrutiny as to their utility, but there is no other shed with a different equipment set.

(4) I am not persuaded of the critique that monomaniacal theorizing is a mode of modernist self-assertion of certainty that cannot withstand the critique of postmodernism. This is not the place to parse the modernism vs. postmodernism debate, except to say that my view of the knowledge produced by the academic study of religion, and the means of producing this knowledge, resists the either/or of modernism and postmodernism. My view of making knowledge in Religionswissenschaft is not modern, if by 'modern' one means a foundational, ahistorical, 'universal human reason', i.e. knowledge and knowing that is historically unsituated and unaware of the conditions in which knowledge is produced, a view that seems, unfortunately, to be regaining currency in the worst of the cognitive science of religion. It is not postmodern either, however, if by 'postmodern' one means the valorisation of 'whatever', of untranslatable 'difference' or 'wholly other' as self-legitimated transcendentals of sorts. ${ }^{11}$ Rather, in my rejection of essentialism or foundationalism - hence my importuning 'corrigibility' above - I am postmodern; in my recoursing to so-called Enlightenment regard for the possibility of conceptuality by means of intellectual labour - both testable and corrigible, of course - as a matter of 'becoming answerable for what we say' (Wolfart 2001) - I am a modernist who stands to be

\footnotetext{
${ }^{11}$ See Smith's caution against use of 'wholly other' language as one finds with R. Otto: '[I]t must be insisted that the language of the "other" always invites misunderstanding, suggesting, as it does, an ontological cleavage rather than an anthropological distinction. Much better is the language of "difference", which is as relational and relative a terminology as the "other" is absolute. "Otherness" blocks language and conceptualization; "difference" invites negotiation and intellection.' (Smith 2004, 241; see also 1992.)
} 
corrected. And as such, I am suspicious of any invocation of postmodernism where I sense that it is used either as a rhetorical device to place some taste, preference, practice, belief, or self-representation beyond criticism, ${ }^{12}$ or as an incantation of the dubious premise of what Ernest Gellner calls the 'egalitarianism of all thought-systems' as the basis for an uninterrogatable admission of 'whatever' into venues of critical thought (see Gellner 1992, 55). This is simply a kind of vulgar liberalism turned into a compost for growing things that I find very frightening, not only because of what they bode for thought itself, but also what they imply socially and politically. By 'things that frighten' I have in mind the very conditions that enchanting priests of postmodernism present as epicurean delight: the 'dedifferentiation' of all things, which, as Fredric Jameson (1991) diagnostically points out, might be seductive (the allure of the exotic) and addictive (the allure of the authentically personal), but which constitutes the conditions for and the effects of the global voracity of late capitalism. For example, permitting myself a hunch (see Antonio 2000): it is the increasingly dedifferentiated world that is perhaps the foundation for the current 'rebirth of the tribe', of the rise of nativisms, presenting themselves in forms of nostalgic, utopian nationalisms and by means of rhetorics of recuperation of something lost (laden with yearning language of origin, indigenism, authenticity, uniqueness, incomparability and so forth, as markers of difference and identity), all in defence against the agonies of global capitalism's 'empire of blur' (Jameson 2003, 74-76; phrase owed to Rem Koolhaas).

The above four points are a way of saying that the study of religion is fundamentally an activity of thought that is not beholden to an a priori foundational premise. It is thus an activity that, to my mind, has not yet given up on the idea of the university as a place for persistent examination and criticism of our and others' (including the university's) cultural sacralities, and for offering its students some resources for explaining the mechanisms and modes whereby these sacralities assume, maintain, or lose their sacredness and the multi-layered cognitive, social, and political effects of super-valuing something as sacred. All this, too, is a long exposition of my unease concerning the oft-repeated lamentation that an anthropocentric study of religion disrespectfully sneers at religious thought-systems, and

\footnotetext{
${ }^{12}$ As a way of correcting the popular meaning of 'criticism' as a synonym for negation or refutation, I should say that I use 'criticism' in the old Greek sense, meaning the will and ability to distinguish and decide (krinein) between options on the basis of standards (kritêria) that are themselves the precipitates of a critical (kritikos) process that now, as in ancient Greek societies, is not esoteric but exoteric, i.e., public.
} 
therefore at the people for whom those systems function as organizers of personal and social identities and practice. ${ }^{13}$

This kind of lamentation is to blame Pandora all over again; it is ultimately to consider curiosity, and its disciplined and intrusive activation, as uncivil, perhaps even inhumane. Allow me clarify what I mean.

As a matter of record and as a plea for a stipulation: the motive force behind representing the study of religion as a non-religious endeavour is neither to pan religion(s) nor to praise religion(s), neither to snipe at religion(s) nor to snuffle for religion. That is to say, the perception of 'disrespect' and 'snub' is entirely a side issue, a kind of peripheral turbulence that appears to be hyper-felt in the study of religion, though it is an endogenous effect of critical thought itself. This discomfort from the turbulence is no reason to still the wind of critical theorizing, either in the study of religion or in the study of anything else.

This turbulence explains, I think, why one is often asked, in more or less explicit ways, to have the 'other' side presented as a 'balance' to what they perceive to be a 'one-sided' or 'unbalanced' representation of the study of religion. Students intuitively prefer to be gatherers and samplers of 'meanings'. Motives may vary, ranging from an unreflected desire to evade the risk of 'reductionist' demystification of their cherished meanings to an articulate preference for what we might call the school of hermeneutic/symbolist anthropology which, now commonly validated by some understanding of 'postmodernism', likes to collect and sniff meanings - though, such is my impression, often remaining majestically cagey ('impartial') with respect to pronouncing whether a particular meaning's bouquet is pleasant or stinky.

My response, condensed here but doled out ad hoc in bits and bites throughout my work in the study and in the classroom, goes something like this:

(1) 'Meanings' indeed are as numerous as a thousand flowers in the garden, so let's stipulate a pluralism of meanings. But the many meanings do not stand in symmetrically 'balanced' relationship to each other for those who have and hold a meaning. At the level of status and function, that is, meanings are generally not held with a sentiment of pluralism or

\footnotetext{
${ }^{13}$ Students of religion regularly feel that this approach 'alienates' people of religious faith. They complain about having their 'foundation rocked'. They contend that an anthropocentric approach does not 'touch the experience of religious people' - though others think it 'touches' the religious experience of people far too roughly. This approach is thought to 'set itself against religion'.
} 
relativism. To be sure, they may be regarded, in one sense, as 'provincial' insofar as 'other' 'provincial' meanings are recognized, even tolerated, but this concessive tolerance of 'other' meanings generally does not de-mean or relativise 'my/our' provincial meaning-complex. The thousand flowers in the garden thus reveal themselves as a thousand provincial absolutes, not as a thousand 'sympathetic relativisms', as Gellner puts it $(1992,50)$. Religious meanings are always somebody's meanings, and have the status of meanings precisely because they cannot be rendered less weighty by the counter-weight (balance) of an other's meaning. What, then, is the scholar to do if he or she is fretting to do something more interesting and intellectually challenging than merely count and catalogue the flowers of meaning in the garden?

(2) Meanings are notoriously inaccessible. I will let Gellner's truculent words carry on: 'one of the temptations to which the hermeneutic school is prone, and to which practitioners of postmodernism succumb with ecstasy [...] [is that] they become so enthusiastic and inebriated with the difficulty of explicating the Other that in the end they don't even try to reach it, but content themselves with elaborating the theme of its inaccessibility, offering a kind of initiation into a Cloud of Unknowing, a Privileged Non-Access [...] a mystery all its own.' (Gellner 1992, 56.) I agree.

(3) Hence, I suggest, we might learn a lot more about religious meanings by paying attention not so much to the flowers in the garden but to the gardener and the gardener's (human) processes of planting, cultivating, fencing off and reaping meanings.

All this to make the point that the problem of a buffeting turbulence effected by an anthropocentric-social-historical theorizing of religion is best solved pedagogically by scrutinizing the problem itself and thoughtfully minding the intrusive nature of introducing thought into the domain the familiarly-known and the exotically strange and other, of introducing as 'poking and prying with a purpose' (Hurston 1942, 74), rather than by permitting the problem to frighten us into abandoning our hell-bent-forleather theorizing ride.

\section{The Hard Road toward Understanding Religion}

Knowing full-well that this 'attitude' is not representative of the field of Religious Studies as a whole, in either its past or its current constellation of practices, we need to ride on. If this manner of introducing religion is thought to be too imperialistic, I would agree only if I am permitted to qualify my imperialism with a coda expressed in Toni Morrison's words: 
I want to draw a map, so to speak, of a critical geography and use that map to open as much space for discovery, intellectual adventure, and close exploration as did the original charting of the New World - without the mandate of conquest (Morrison 1993, 3, emphasis added).

Empires are built on and continuously shored up by what Wilfred Sellars calls 'the myth of the given' (Sellars 1997; see also Penner 2000). The truly imperial modes of imperializing are assertions of power and the rhetoric of assimilation - which, of course, may well represent themselves in various platitudinous nods toward 'pluralism' (see Brown 2006) ${ }^{14}$ but such that 'pluralism' is sharply contained either with reference to the 'private' or to the 'personal' - or a way of talking to ourselves among ourselves within (concessively acknowledged but ignored) earshot of the noise of other folks talking to themselves. Hence an imperialism that represents itself as corrigible is actually quite an oxymoron, thus not an imperialism at all. Since the academic field of Religionswissenschaft is at this time actually ruled by different disciplinary attitudes, ${ }^{15}$ the stance recommended here is merely an assertion of a kind of work on religion that refuses to be assimilated, the kind of work that insists on 'a trained and scrutinized consciousness' as the sine qua non in the academy's human and social sciences, including Religious Studies. And what is this? Nothing grander than the 'sheer survival' of the most humane road to understanding human societies, what J. Z. Smith calls 'the hard road of understanding' (1985a, 546), because it must labour for its insights and contend for them in the arena of public argument in the academy, rather than wait passively for visions and expect revelations.

What this means for the disciplinary practices of scholars of religion, particularly the mandate of introducing religion in the context of a general education, can here be indicated only briefly in terms of clues. It means, I think, finally (finally!) restraining ourselves from employing taxonomies of religion that are binary in structure: whether qualitative binaries, such as true vs. false, revealed vs. natural, universal vs. particular, ours vs. theirs, or historico-evolutionary binaries, such as prehistorical vs. historical, primi-

\footnotetext{
${ }^{14}$ Brown argues the thesis that the rhetoric of tolerance is 'a mode of incorporating and regulating the presence of the threatening Other within' $(2006,27)$, a regulating and nation-governing device that 'manages the demands of marginal groups in ways that incorporate them without disturbing the hegemony of the norms that marginalize them' $(2006,36)$. For a roughly similar analysis of the virtue of pluralism espoused in the study of religion at its most spectacular official site (the American Academy of Religion), see Wolfart 2001.

${ }^{15}$ This is really another story; see Arnal \& Braun (forthcoming) for an argument that Religious Studies is historically and fundamentally a theologically constituted field.
} 
tive vs. advanced, animist vs. rational, cosmotrophic vs. soteric (Alles 1994, 104-106), and so forth. These binaries - and others we might think of - are ethnocentrically prejudiced. ${ }^{16}$ As Tim Murphy has reminded us recently, in these bi-modal taxonomies the "paired oppositions [...] are not equally weighted. [...] [B]inary pairs actually form hierarchical oppositions.' (2006, 202.) Moreover, not only do they fail to have empirical and sound logical warrant, ${ }^{17}$ but they are also inhumane. It also means, I suggest as a second clue, creating and using definitions of our object(s) without creating essences, something that is quite possible to do. ${ }^{18}$ Essences are born out of a mythic imagination, but when deployed ideologically and politically they are not just 'acts of metaphysical aggression', as Dubuisson would say $(2003,167$; see profitably also Fitzgerald 2000), but pernicious tools of apologetics, vilification, and conquest. And that too is inhumane. This entails, as a third clue, that the vast data field that we (by some stipulated set of markers) nominally call 'religion' or 'religious' (or by some other name for a beyond-history and beyond-language - i.e., nonhuman = inhuman? - ontos) is not subject to a single capital-T Theory of religion, because such a theory would need to presuppose a generic and thus non-historical human being. In that case the theory would not be able to escape being a 'disincarnate idealization'

\footnotetext{
16 'Ethnocentrism' condenses features of a familiar mode of representing social identities in the past, but not only in the past: asymmetrical evaluations of historical social identities (e.g., Greeks vs. Barbarians, Christians vs. Jews or Pagans, Us vs. Them); monocentric and monogenetic origins (on which see also Smith 2001a); historical continuity that is often combined with a failure to respect the distinction between 'then' and 'now' and 'here' and 'there'; a preference for teleological history over contingent history. For elaboration see Rüsen 2004; on the 'synchrony of now and then' see Zerubavel 2003, 46-48. In my field of research, the history and historiography of early Christianities, this ethnocentrism is often explicitly linked to the rhetoric of uniqueness in which comparison is ruled by 'an overwhelming concern for assigning value, rather than intellectual significance, to the results of comparison', as Jonathan Z. Smith has demonstrated (1990, 46). See also Smith 1985b; 1992.

${ }_{17}$ This is not a new insight, of course. It has become a mantra in recent reflection on historical classificatory practices within Religionswissenschaft. Note especially the work of Jonathan Z. Smith, Tim Fitzgerald, Russell McCutcheon, inter al. See now also Dubuisson 2003, 199-200; and Masuzawa 2005.

${ }^{18}$ See most recently Stowers 2007, 14: 'Neo-Darwinian biology can teach us how to use definitions without creating essences. In biology, a species has no essence and shades into continuity and complex relations of similarity and difference with other species and varieties that are always changing. But the lack of boundaries, the complex changing continuities and discontinuities, do not mean that we cannot usefully and rightly think of plants and animals or human forms of sociality as grouping in significant ways - ways significant to us - across the varieties of time and place. The criteria for identifying a form of human sociality, like a species, do not need to claim universality and unblurred boundaries, but only to be broadly and reliably generalizable.'
} 
(Dubuisson 2003, 110) and thus offer no aid at all in the description and understanding of the parochiality, particularity, and historicality of social formations and their practices in various times and places. But it is only thus that these parochial, private experiences are given their human and humane due - a scholarly due that the scholar of religion donates to the project and prospect of humanity (see Saxton 2006).

Bibliography

Adorno, Theodor W.

1964 Jargon der Eigentlichkeit. Zur deutschen Ideologie. Frankfurt am Main: Suhrkamp.

Alles, Gregory D.

1994 The Iliad, the Ramayana, and the Work of Religion. Failed Persuasion and Religious Mystification. University Park: Pennsylvania State University Press.

Antonio, Robert J.

2000 After Postmodernism. Reactionary Tribalism. - American Journal of Sociology 106, 40-87.

Arnal, William E.

2000 Definition. - Willi Braun \& Russell T. McCutcheon (eds), Guide to the Study of Religion, 21-34. London: Cassell.

\section{Arnal, William E. \& Willi Braun}

2004 Social Formation and Mythmaking. Theses on Key Terms. - Ron Cameron \& Merrill Miller (eds), Redescribing Early Christianity, 459-69. Atlanta: Society of Biblical Literature; Leiden: Brill. (Society of Biblical Literature Symposium Series, 28.)

Forthcoming Does Theology Belong in Religious Studies? - Brad Verter \& Johannes C. Wolfart (eds), Rethinking Religion 101. Praxis, Pedagogy and the 'Religion Question'. Cambridge: Cambridge University Press.

Braun, Willi \& Russell T. McCutcheon (eds)

2000 Guide to the Study of Religion. London: Cassell.

Braun, Willi

2000 Religion. - Willi Braun \& Russell T. McCutcheon (eds), Guide to the Study of Religion, 3-18. London: Cassell.

2001 The Blessed Curse of Thought. Theorizing Religion in the Classroom. - ARC. The Journal of the Faculty of Religious Studies (McGill University) $29,161-77$. 


\section{Brown, Wendy}

2006 Regulating Aversion. Tolerance in the Age of Identity and Empire. Princeton: Princeton University Press.

\section{Certeau, Michel de}

1984 The Practice of Everyday Life. S. Redall (trans.). Berkeley: University of California Press.

\section{Comaroff, John}

1982 Dialectical Systems, History, and Anthropology. Units of Study and Questions of Theory. - Journal of Southern African Studies 8, 143-72.

\section{Comaroff, John \& Jean Comaroff}

1992 Ethnography and the Historical Imagination. Boulder, Colorado: Westview.

\section{Dawkins, Richard}

1982 The Extended Phenotype. The Gene as the Unit of Selection. San Francisco: Freeman.

\section{Desjardins, Michel}

2001 Teaching with the Guide to the Study of Religion. - ARC. The Journal of the Faculty of Religious Studies (McGill University) 29, 139-50.

\section{Dubuisson, Daniel}

2003 The Western Construction of Religion. Myths, Knowledge, and Ideology. W. Sayers (trans.). Baltimore: Johns Hopkins University Press.

\section{Fitzgerald, Timothy}

2000 The Ideology of Religious Studies. Oxford: Oxford University Press.

Gardaz, Michel (ed.)

2006 Religious Studies in Canada. Past, Present, and Future. (Special Issue, Studies in Religion/Sciences Religieuses 35, 3-4.)

\section{Gellner, Ernest}

1992 Postmodernism, Reason and Religion. London: Routledge.

\section{Griffiths, Gareth}

1989 The Myth of Authenticity. Representation, Discourse and Social Practice. - Chris Tiffin \& Alan Lawson (eds), De-Scribing Empire. Post-colonialism and Textuality, 70-85. London: Routledge.

\section{Harris, Marvin}

1980 Cultural Materialism. The Struggle for a Science of Culture. New York: Vintage.

Hertz, Judith (ed.)

1994 Fields and Boundaries. The Shifting Space of Disciplinarity. Ottawa: Canadian Federation for the Humanities/Fédération canadienne des études humaines. 


\section{Hurston, Zora Neale}

1942 Dust Tracks on a Road. Urbana: University of Illinois Press.

\section{Jameson, Fredric}

1991 Postmodernism, or, The Cultural Logic of Late Capitalism. Durham, North Carolina: Duke University Press.

2003 Future City. - New Left Review 21 (May-June), 65-79.

\section{Masuzawa, Tomoko}

2005 The Invention of World Religion, or, How European Universalism Was Preserved in the Language of Pluralism. Chicago: University of Chicago Press.

McCutcheon, Russell T.

2003 The Jargon of Authenticity and the Study of Religion. - Russell T. McCutcheon, The Discipline of Religion. Structure, Meaning, Rhetoric, 167-88. New York: Routledge.

2007 Studying Religion. An Introduction. London: Equinox.

Messer-Davidow, Ellen \& David R. Shumway \& David J. Sylvan (eds)

1993 Knowledges. Historical and Critical Studies in Disciplinarity. Charlottesville: University Press of Virginia.

\section{Micheelsen, Arun}

2002 'I Don't Do Systems.' An Interview with Clifford Geertz. - Method \& Theory in the Study of Religion 14, 2-20.

\section{Morrison, Toni}

1993 Playing in the Dark. Whiteness and the Literary Imagination. New York: Knopf.

\section{Murphy, Tim}

2006 Cultural Understandings of 'Religion'. The Hermeneutical Context of Teaching Religious Studies in North America. - Method \& Theory in the Study of Religion 18, 197-218.

\section{Penner, Hans D.}

2000 Interpretation. - Willi Braun \& Russell T. McCutcheon (eds), Guide to the Study of Religion, 57-71. London: Cassell.

Forthcoming What a Difference Theory Makes. - Willi Braun \& Russell T. McCutcheon (eds), Introducing Religion. London: Equinox.

\section{Pope, Alexander}

1733 An Essay on Man. London: Printed for J. Wilford. (Facsimile edition, Menston: Scolar, 1969.)

\section{Rüsen, Jörn}

2004 How to Overcome Ethnocentrism. Approaches to a Culture of Recognition by History in the Twenty-First Century. - History and Theory $43,118-29$. 


\section{Saxton, Alexander}

2006 Religion and the Human Prospect. New York: Monthly Review Press.

Sayeed, S. M. A.

1995 The Myth of Authenticity. A Study in Islamic Fundamentalism. Karachi: Royal Book Co.

\section{Sellars, Wilfrid}

1997 Empiricism and the Philosophy of Mind. Cambridge: Harvard University Press.

Smith, Jonathan Z.

1978 Map Is Not Territory. Studies in the History of Religions. Leiden: Brill. Reprint, Chicago: University of Chicago Press, 1993. (Studies in Judaism in Late Antiquity, 23.)

1982 Imagining Religion. From Babylon to Jonestown. Chicago: University of Chicago Press. (Chicago Studies in the History of Judaism.)

1985a Jonathan Z. Smith on William J. Bennett's 'To Reclaim a Legacy. A Report on the Humanities in Higher Education'. - American Journal of Education 93, 541-46.

1985b What a Difference a Difference Makes. - Jacob Neusner \& E. S. Frerichs (eds), 'To See Ourselves as Others See Us.' Christians, Jews, 'Others', in Late Antiquity, 3-48. Chico, California: Scholars Press.

1990 Drudgery Divine. On the Comparison of Early Christianities and the Religions of Late Antiquity. London: School of Oriental and African Studies, University of London; Chicago: University of Chicago Press. (Jordan Lectures in Comparative Religion, 14.)

1992 Differential Equations. On Constructing the Other. The University Lecture in Religion, 13, Arizona State University, Tempe, Arizona.

2001a Close Encounters of Diverse Kinds. - Susan L. Mizruchi (ed.), Religion and Cultural Studies, 3-21. Princeton: Princeton University Press.

2001b A Twice-told Tale. The History of the History of Religions' History. - Numen 48, 131-46.

2004 Relating Religion. Essays in the Study of Religion. Chicago: University of Chicago Press.

2007 Afterword. The Necessary Lie. Duplicity in the Disciplines. - Russell T. McCutcheon, Studying Religion: An Introduction. London: Equinox.

\section{Sperber, Dan}

1996 Explaining Culture. A Naturalistic Approach. London: Blackwell.

\section{Steinthal, Heymann}

1863 Geschichte der Sprachwissenschaft bei den Griechen und Römern, mit besonderer Rücksicht auf die Logik. Berlin: F. Dümmler's Verlagsbuchhandlung.

\section{Stowers, Stanley}

2007 The Concept of 'Religion,' ‘Political Religion' and the Study of Nazism. - Journal of Contemporary History 42, 9-24. 
Forthcoming The Ontology of Religion. - Willi Braun \& Russell T. McCutcheon (eds), Introducing Religion. London: Equinox.

\section{Thompson Klein, Julie}

1996 Crossing Boundaries. Knowledge, Disciplinarities, and Interdisciplinarities. Charlottesville: University Press of Virginia.

Whitcombe, Anne

2001 Seeking Guidance. One Student's Critical Reflection on Using the Guide to the Study of Religion. - ARC. The Journal of the Faculty of Religious Studies (McGill University) 29, 151-60.

Wolfart, Johannes C.

2001 Becoming Answerable for What We Say. Colonialism and the Pax AAR. - Studies in Religion / Sciences Religieuses 30, 381-88.

\section{Zerubavel, Eviatar}

2003 Time Maps. Collective Memory and the Social Shape of the Past. Chicago: University of Chicago Press. 